\title{
DAMPAK PELAKSANAAN PERLINDUNGAN LINGKUNGAN MELALUI SERTIFIKASI FAIR TRADE (Studi Kasus: Petani Kopi Anggota Koperasi Permata Gayo, Kabupaten Bener Meriah, Nanggroe Aceh Darussalam)
}

\author{
Fahnia Chairawaty \\ Kajian Ilmu Lingkungan, Program Pascasarjana, Universitas Indonesia, \\ Kampus UI Depok, Jl. Salemba Raya 4, Jakarta 10430, Indonesia \\ E-mail: sayya_chaira@yahoo.com
}

\begin{abstract}
ABSTRAK
Tujuan dari penelitian ini adalah untuk menganalisis dan mengidentifikasi dampak dari pelaksanaan perlindungan lingkungan yang dilakukan oleh para petani kopi anggota Koperasi Permata Gayo (KPG), setelah mereka mendapatkan sertifikasi fair trade (FT). Perlindungan lingkungan sendiri adalah salah satu kewajiban utama yang harus dilakukan oleh para petani kopi yang telah bergabung dalam FT. Penelitian ini menggunakan teori pembangunan berkelanjutan yang juga merupakan prinsip dasar dari FT. Untuk itu dampak dari perlindungan lingkungan dalam penelitian ini akan dikaji berdasarkan aspek ekonomi, sosial dan lingkungan, yang juga merupakan aspek-aspek pendukung dalam pembangunan berkelanjutan. Pembahasan dalam penelitian ini akan ditekankan pada pelaksanaan perlindungan yang telah dilakukan oleh para petani KPG, isu-isu terkait lingkungan yang dihadapi oleh petani, serta dampak dari perlindungan sendiri yang dirasakan oleh para petani kopi KPG. Pendekatan dalam penelitian ini adalah pendekatan kualitatif dengan metode survei berupa wawancara mendalam, snowball dan observasi, serta dengan metode studi literatur. Hasil dari penelitian ini berkesimpulan bahwa dampak dari perlindungan lingkungan yang dirasakan oleh petani kopi KPG cenderung lebih besar dirasakan pada dampak ekonomi, yaitu berkurangnya biaya pembelian input kimia

Kata kunci : Petani kopi, Perlindungan Lingkungan, Sertifikasi Dagang, Pengaruh, Pembangunan berkelanjutan.

ABSTRACT

The aims of this research was to analized and identified about the impacts of environmental protection that implemented by coffee farmers, members of Koperasi Permata Gayo (KPG), after they get Fair Trade (FT) certification. Protection of the environment itself is one of the primary obligation that must be carried out by the coffee farmers who have joined the FT. This study uses the theory of sustainable development which is also the basic principles of the FT. For the impact of environmental protection in this study will be assessed based on the economic, social and environmental aspect, both aspects become the supporting aspects in sustainable development. This research will focussing on the implementation of environmental protection that have been carried out by the KPG farmers, environment related issues faced by the farmers, and the impact of environmental protection that perceived by coffee farmers, members of KPG. The approach in this research is a qualitative approach, with a survey method using in-depth interviews, snowball techniques, observation techniques, and also used literature study method. The results of this study concluded that the impact of perceived environmental protection by KPG coffee growers tend to be larger on economic impact, which reduce the cost of purchasing chemical inputs.
\end{abstract}

Keywords: Coffee Farmers, Environmental Protection, Fair Trade Sertification, Impact, Sustainable Development

\section{Pendahuluan}

Fair trade (FT), yang sering diterjemahkan menjadi perdagangan adil atau perdagangan berkeadilan, muncul sebagai sebuah gerakan sosial dengan pendekatan berbasis pasar yang bertujuan mengurangi kemiskinan di tingkat global dan mempromosikan sistem perdagangan berkelanjutan. Bibit-bibit dari gerakan ini mulai lahir pada tahun '40-an di dunia barat, 
namun baru mulai berjalan secara signifikan pada tahun '80-an (Salam, 2003). Sejak kemunculannya FT adalah sebuah gerakan perdagangan alternatif yang memperjuangkan adanya jaminan harga pembelian yang adil sekaligus memperbaiki kondisi sosial dan lingkungan bagi komunitas produsen. Perkembangan FT di Indonesia sendiri baru dimulai pada pertengahan tahun 1980-an. Dalam perkembangannya FT di Indonesia telah cukup membantu produsen-produsen miskin di berbagai wilayah seperti Yogyakarta, Malang, Mataram, Bali hingga Aceh (Nuraliyah, 2007).

Secara fundamental, FT merupakan sebuah respon atas kegagalan dari pasar konvensional dalam rangka memberikan kehidupan yang berkelanjutan dan memberikan kesempatan bagi orang-orang di negaranegara miskin di dunia. Hal ini dibuktikan dengan jumlah penduduk miskin di dunia yang kurang lebih mencapai angka dua milyar. Kebanyakan dari mereka menghadapi kondisi kerja yang berat dan buruk, dengan upah rata-rata kurang dari 2 dolar per hari. Kemiskinan membuat mereka tidak memiliki pilihan, sementara tekanan pasar membuat mereka semakin termarjinalisasi dan terabaikan. Hal ini juga membuat mereka semakin rentan terhadap degradasi lingkungan (WFTO, 2008).

Salah satu hal yang harus dipenuhi agar para petani di negara-negara berkembang dapat ikut serta dalam gerakan ini adalah dengan memiliki sertifikasi FT. Untuk mendapatkan sertifikasi FT ini mereka harus membentuk atau bergabung di bawah organisasi lokal (seperti koperasi). Organisasi atau koperasi inilah yang nantinya akan mendaftarkan para petani tersebut untuk mendapatkan sertifikasi FT. Dengan skema seperti ini produsen kecil seperti petani tidak terbebani dengan biaya sertifikasi yang tinggi. Setelah mendapatkan sertifikasi FT, organisasi produsen tersebut harus melakukan beberapa hal seperti penguatan organisasi, pendokumentasian kegiatan dan produksi, membuat laporan dan menerima kunjungan inspektor Fairtrade Labelling Organization (FLO), yang akan datang ke lokasi secara periodik baik dalam hal pembinaan maupun dalam hal audit (Suhartana dan Sumino, 2009). FLO sendiri adalah organisasi nirlaba yang bertanggung jawab atas arahan dan eksekusi, menetapkan standar dan mendukung produsen maupun pedagang dalam aktivitas perdagangan di dalam FT.

FT dapat pula diartikan sebagai sebuah gerakan, proses ataupun seperangkat prinsip. Produkproduk FT dapat diidentifikasi menjadi dua jenis, yaitu: 1. Produk yang secara spesifik telah mendapatkan sertifikasi dari organisasi Fairtrade International/FLO; 2. Produk-produk yang dijual oleh para penjual yang merupakan anggota dari FLO yang diakui oleh komunitas FT (Stenzel, 2012). Label FT diberikan kepada produk (kebanyakan produk-produk pangan) yang diimpor dan diproduksi di negara-negara berkembang, sesuai dengan kesepakatan sosial dan lingkungan yang tertuang dalam konvensi International Labor Organization (ILO) dan rekomendasi Agenda 21

(C) 2012, Program Studi Ilmu Lingkungan Program Pasca Sarjana UNDIP oleh Perserikatan Bangsa-Bangsa (PBB) (Loureiro \& Lotade, 2005).

Secara spesifik FLO mendefinisikan dua kriteria bagi produsen yang ingin ikut serta dalam FT. Kriteria yang pertama adalah produsen kecil, dan yang kedua adalah mereka yang bekerja sebagai pekerja di perkebunan atau industri (FLO dalam Gendron et al., 2009). Lebih lanjut lagi, menurut FLO standar minimal (bagi para kelompok produsen kecil) yang harus benarbenar dimiliki, yaitu adanya kemauan untuk melakukan praktek perlindungan lingkungan. Praktek perlindungan yang dimaksud adalah praktek perlindungan pada lingkungan alam dan menjadikan perlindungan lingkungan sebagai bagian dari manajemen pertanian yang mereka lakukan (FLO, 2005). FT cukup menghargai dan mendorong praktek pertanian dan produksi yang berkelanjutan secara lingkungan. Para produsen juga didorong untuk berusaha menerapkan prinsip-prinsip organik (FLO, 2010).

Bentuk perlindungan lingkungan yang harus dilakukan oleh para produsen adalah (FLO, 2011): 1. Manajemen lingkungan; 2. Penanganan hama terpadu; 3. Penjagaan sumber daya tanah dan air; 4. Pengelolaan limbah; 5. Pelarangan untuk menggunakan organisme hasil rekayasa genetis; 6. Menjaga keanekaragaman hayati; 7. Energi dan gas rumah kaca (GRK), yaitu memperkuat keberlanjutan sistem produksi lokal dengan menurunkan ketergantungan kepada input eksternal untuk adaptasi terhadap perubahan iklim.

Prinsip perlindungan lingkungan yang diterapkan dalam FT ini sebenarnya mengacu kepada prinsip keragaman dalam lingkungan. Usaha perlindungan tanaman secara alami dengan prinsip keragaman hasilnya memang tidak dapat dibandingkan dengan hasil penggunaan pestisida kimia dalam jangka pendek, tetapi yang perlu diperhatikan adalah manfaat komparatif dalam jangka panjang (Sutanto, 2002). Menurut Suhartana (2008), selain harga produk yang lebih baik, petani juga mendapatkan keuntungan dari peningkatan kualitas lingkungan yang ada, yaitu: 1 . Meningkatnya kesuburan tanah; 2. bertambahnya keragaman hayati; 3. Ketahanan tanaman terhadap perubahan cuaca; 4. Berkurangnya biaya pembelian input kimia; 5. Penambahan penghasilan dari tanaman sampingan; 6. Pemanfaatan tenaga lokal untuk menciptakan lapangan kerja; 7. Kuatnya organisasi petani untuk produksi dan pemasaran; 8. Peningkatan kesehatan para petani lokal.

Salah satu produk pertanian organik bersertifikasi FT yang diminati oleh banyak konsumen di belahan dunia adalah kopi. Kurang lebih sekitar 240 produsen kopi di seluruh dunia telah ikut serta dalam sertifikasi FT ini (Loureiro \& Lotade, 2005). Selama beberapa dekade terakhir ini derasnya perkembangan dalam hal sertifikasi kopi secara nyata telah mengindikasikan adanya insiatif untuk meningkatkan pola pertanian ramah lingkungan dan juga tanggung jawab sosial dalam sistem produksi maupun perdagangan kopi (Valkila \& Nygren, 2009). Kopi sendiri adalah salah satu produk pertanian organik di Indonesia yang telah diakui dan memiliki pasar 
internasional. Pada tahun 2011 yang lalu produksi kopi Indonesia mencapai $600 \mathrm{ribu}$ ton/tahun dan lebih dari 80\%-nya berasal dari perkebunan rakyat. Jumlah ini diperkirakan akan meningkat pada periode berikutnya mengingat pangsa pasar ekspor dan kebutuhan konsumsi yang tinggi terhadap kopi. Kegiatan konsumsi yang tinggi ini akan mempunyai dampak ekologis yang tinggi pula sebagai akibat gaya hidup manusia yang pada ujungnya bertumpu pada kemampuan sumber daya alam untuk menyediakan kecukupan pemenuhan bahan baku tersebut (Arief et al, 2011).

Di Indonesia, daerah yang cukup terkenal sebagai daerah penghasil kopi adalah Dataran Tinggi Gayo yang terletak di Provinsi Nanggroe Aceh Darussalam. Sebagai salah satu daerah penghasil kopi terbesar di Indonesia, lingkungan alam yang ada di Dataran Tinggi Gayo memang sangat cocok dan sesuai untuk menghasilkan kopi dengan kualitas baik seperti jenis arabika. Karena itu kopi pun telah menjadi komoditas utama perekonomian masyarakat di wilayah yang terdiri atas tiga kabupaten ini (Aceh Tengah, Bener Meriah dan Gayo Lues). Banyaknya jumlah petani kopi di Dataran Tinggi Gayo juga mengindikasikan betapa pentingnya kopi bagi masyarakat Gayo, tidak hanya pada sisi ekonomis, tapi juga sosial dan lingkungan. Ketiga daerah yang berada di ketinggian $1200 \mathrm{~m} \mathrm{dpl}$ tersebut memiliki perkebunan kopi terluas di Indonesia, dengan luas lahan kurang lebih 94.800 ha. Di Kabupaten Bener Meriah misalnya, terdapat perkebunan kopi seluas 45.316,15 ha yang lebih dari setengahnya merupakan areal perkebunan yang masih produktif (BPS Bener Meriah, 2011).

Sejak diperkenalkannya sertifikasi FT di Dataran Tinggi Gayo pada tahun 2005, hingga saat ini sudah ada 13 koperasi yang memegang sertifikasi FT. Salah satu koperasi kopi yang telah mendapatkan sertifikasi FT adalah Koperasi Permata Gayo (KPG), yang berlokasi di Kabupaten Bener Meriah. KPG sendiri telah mendapatkan sertifikasi FT sejak tahun 2008. Saat ini KPG sudah memiliki 3.089 orang anggota yang tersebar di Kabupaten Aceh Tengah dan Bener Meriah. Sebanyak 100\% anggotanya adalah sudah bersertifikasi FT (Transfairusa, 2011).

Salah satu dampak nyata dari sertifikasi FT adalah penjualan kopi dengan penerimaan ekstra atau tambahan diluar harga beli yang disebut dengan dana premium (premium fee), kopi yang merupakan feedback dari pembeli kepada petani/produsen. Di sisi lain,bentuk-bentuk perlindungan lingkungan yang disyaratkan dalam FT tersebut, jika semua dapat dilakukan dengan baik, tentunya akan menghasilkan dampak positif bagi para petani lokal yang ikut serta dalam jaringan FT di Dataran Tinggi Gayo itu sendiri. Walaupun pelaksanaan perlindungan lingkungan yang diwajibkan dalam FT tidak mudah, tetapi skema premium fee dan pemberdayaan yang menjadi kelebihan dari FT seharusnya dapat digunakan untuk mendukung pelaksanaan perlindungan lingkungan tersebut. Untuk itu penelitian ini bertujuan untuk menganalisis dan mengidentifikasi dampak dari aktivitas perlindungan (C) 2012, Program Studi Ilmu Lingkungan Program Pasca Sarjana UNDIP lingkungan yang dirasakan oleh para petani kopi anggota KPG setelah keikutsertaan mereka dalam FT.

\section{Metode dan Teknik}

Sebelumnya telah banyak penelitian-penelitian lain mengenai FT kopi di dunia yang membahas mengenai dampak-dampak yang diterima oleh petani kopi bersertifikasi FT. Namun demikian, jarang sekali ada penelitian yang secara spesifik meneliti dampak dari FT berdasarkan kewajiban perlindungan lingkungan yang disyaratkan dalam FT. Salah satu studi dari Bacon (2005) mengenai dampak sertifikasi FT pada petani kopi di Nikaragua menghasilkan beberapa temuan terkait dampak dari pelaksanaan perlindungan lingkungan. Pertama, adanya diferensiasi produk, dengan menanam tanaman lain diantara pohon kopi, seperti pohon pisang dan sitrus menghasilkan tambahan pendapatan bagi para petani. Kedua, berkurangnya biaya produksi dan meningkatnya kualitas produk karena tidak digunakannya lagi bahanbahan kimia berbahaya di dalam perkebunan kopi mereka. Ketiga, para petani dapat merekrut lebih banyak tenaga kerja, terutama dari kalangan kerabat dekat (penciptaan lapangan kerja). Sementara itu penelitian Ruben \& Fort (2011) di Peru menghasilkan temuan berbeda. Dampak yang signifikan justru terlihat pada penggunaan pupuk kimia yang masih digunakan oleh petani non-FT dan sebaliknya pada petani FT.

Pada penelitian ini sendiri, digunakan pendekatan kualitatif karena peneliti ingin mencari makna di balik fenomena atau kenyataan yang ada di lapangan. Metode kualitatif yang digunakan dalam penelitian ini adalah, observasi, wawancara mendalam, snowball, dan studi literatur. Populasi dalam penelitian ini adalah pihakpihak utama yang tergabung dalam jaringan FT di Kabupaten Bener Meriah, Dataran Tinggi Gayo. Untuk itu penentuan responden dalam penelitian ini digunakan pendekatan purposive sampling yang merupakan jenis pendekatan berdasarkan kriteria. Kriteria-kriteria yang digunakan untuk pemilihan responden tersebut adalah:

1. Para petani kopi anggota KPG, dengan kriteria: (a) Telah menjadi anggota koperasi minimal 3 tahun; (b) Telah mendapat sertifikasi FT; (c) Telah menerima premium fee; (d) Lokasi kebun berada di wilayah Kabupaten Bener Meriah; (e) Berdomisili di Kabupaten Bener Meriah.

2. Pengurus KPG yaitu, ketua koperasi, manajer atau koordinator lapangan, serta ketua divisi sertifikasi.

3. Perwakilan FLO (organisasi) yang melakukan monitoring secara berkala setiap tahun.

4. Perwakilan Dinas Perkebunan dan Kehutanan Kabupaten Bener Meriah.

Pengolahan data dalam penelitian ini akan dilakukan melalui koding yang diikuti dengan analisis teks dan content analysis. Data yang diperoleh melalui teknik wawancara mendalam dan observasi akan diolah menggunakan analisis teks dengan metode interpretasi dan akan disajikan secara deskriptif. Data yang didapat 
dari dokumen (studi literatur) akan diolah menggunakan content analysis, dan disajikan secara deskriptif eksplanatif. Sementara data yang didapat dari hasil observasi akan disajikan dalam bentuk tabulasi dan juga deskriptif.

\section{Hasil dan Pembahasan \\ Bentuk-bentuk perlindungan lingkungan yang dilakukan oleh petani kopi KPG sesuai standar FT.}

Dalam standar FT manajemen lingkungan adalah salah satu hal utama yang harus dilakukan. Manajemen lingkungan yang dilakukan oleh organisasi produsen seperti KPG terkendala oleh hambatanhambatan struktural (hambatan internal) seperti keterbatasan sumber daya manusia (SDM), komunikasi, hingga regulasi terkait sanksi yang masih lemah, sehingga koordinasi antara KPG dan para petani KPG masih kurang. Pelaksanaan manajemen lingkungan yang masih belum berjalan dengan baik ini pada akhirnya berdampak pada jumlah rata-rata produksi kopi petani KPG yang hanya berkisar 600-700 kg/ha/tahun. Sementara jumlah ideal per ha-nya adalah \pm 1.000 $\mathrm{kg} / \mathrm{ha} /$ tahun.

Penanganan hama, seperti yang tercantum dalam standar FT adalah berupa penanganan hama terpadu, yaitu penanganan hama yang aman dari bahan kimia berbahaya, dan adanya pelatihan yang diberikan oleh organisasi produsen kepada para petani dalam penanganan hama. Berdasarkan hasil observasi dan wawancara, sejauh ini para petani KPG sudah banyak (sekitar 90\%-nya) yang tidak menggunakan bahanbahan kimia dalam penanganan hama atau gulma. Para petani sudah tidak banyak lagi yang menggunakan herbisida untuk memberantas gulma di perkebunan mereka.

Pelatihan untuk penanganan hama seperti hama penggerek buah yang menyerang pohon kopi juga sudah diberikan kepada petani. Namun dalam pelaksanaannya praktek penanganan hama tersebut belum dilakukan oleh petani. Hal ini dikarenakan masih kurangnya material pendukung, serta masih belum pahamnya petani dalam praktek penanganan hama tersebut walaupun sudah diberikan pelatihan. Untuk menangani hama ini juga diperlukan sebuah aksi kolektif, minimal oleh para petani KPG yang perkebunannya berada dalam satu wilayah desa yang sama. Hal ini mengingat sifat dan penyebaran hama yang begitu cepat dan massif dalam lingkungan perkebunan kopi.

Standar yang ketiga adalah aktivitas perlindungan lingkungan yang berkaitan dengan penjagaan sumber daya tanah dan air. Salah satu aktivitas perlindungan lingkungan berkaitan dengan penjagaan sumber daya tanah adalah dengan praktek pertanaman campuran atau agroforestry yang juga berkaitan erat dengan sifat dari tanaman kopi sendiri yang membutuhkan tanaman peneduh untuk mengurangi intensitas cahaya matahari. Tidak hanya tanaman peneduh, tanaman lain yang juga diperlukan untuk menjaga sumber daya tanah dalam perkebunan (C) 2012, Program Studi Ilmu Lingkungan Program Pasca Sarjana UNDIP kopi adalah penggunaan penutup tanah. Penggunaan penutup tanah di sini adalah dengan menanam tanaman-tanaman yang berfungsi untuk menjaga tanah dari erosi dan memperbaiki sifat kimia atau fisik tanah. Selain penggunaan tanah cara lain untuk memperbaiki sifat kimia dan fisik tanah adalah dengan menggabungkan kompos atau tanaman hijau ke dalam tanah (FLO, 2011).

Sejauh ini hampir semua petani KPG telah menanam tanaman peneduh di perkebunan kopi mereka. Hal ini terlihat dari rata-rata perkebunan kopi petani KPG yang juga terdiri dari tanaman-tanaman peneduh seperti lamtoro, petai cina, jeruk, dan lain-lain. Walaupun demikian jenis dan jumlah pohon pelindung yang ditanam oleh petani masih sangat terbatas. Sebagian petani juga telah menggunakan penutup tanah di dalam perkebunan mereka, seperti menggunakan tanaman labu air, kacang-kacangan, dan lain-lain. Sementara itu baru sedikit petani yang dengan sengaja menggabungkan kompos atau tanaman hijau ke tanah. Biasanya praktek semacam ini mereka lakukan dengan membuat 'lubang angin' sebagai lubang untuk mereka menaruh tanaman-tanaman hijau dari sekitar perkebunan, untuk kemudian dapat dibuat menjadi kompos.

Untuk menjaga sumber daya tanah dan air, dalam standar FT petani juga diarahkan untuk melakukan tindakan pencegahan erosi lahan dan juga membuat buffer zone disekeliling kawasan perkebunan mereka, terutama yang berada dekat dengan sumber air. Sejauh ini, menurut pengurus KPG belum ada petani KPG yang melakukan langkah pencegahan terhadap erosi lahan seperti melakukan terasering, walaupun pelatihan sudah diberikan. Akibatnya untuk beberapa wilayah perkebunan petani yang cukup landai, masih sering dijumpai terjadinya erosi lahan. Sementara itu, sudah ada petani KPG (terutama yang berada dekat dengan sumber air) yang membuat buffer zone di sekeliling perkebunan mereka.

Para petani KPG juga sudah diajarkan cara membuat pupuk organik melalui pelatihan yang diadakan bagi para delegasi (yang merupakan perwakilan dari yang ditunjuk secara langsung oleh para petani di tiap-tiap desa). Namun demikian, masih sedikit petani KPG yang membuat pupuk organik sendiri, sesuai dengan yang diajarkan di dalam pelatihan. Kebanyakan petani masih menggunakan pupuk organik dari kulit kopi, yang memang sudah secara turun temurun digunakan oleh para petani kopi di Dataran Tinggi Gayo.

Bentuk perlindungan lain yang juga harus dilakukan oleh petani sesuai dengan standar FT adalah melakukan penanganan limbah. Seperti yang disebutkan sebelumnya, untuk limbah organik (penanganannya adalah dengan mengolahnya menjadi pupuk organik) belum sepenuhnya dilakukan oleh petani. Penggunaan limbah organik hanya terbatas pada penggunaan kulit kopi saja untuk diolah menjadi pupuk organik. Penanganan limbah berupa sampah non-organik seperti plastik belum dilakukan oleh petani KPG. Hingga saat ini sampah-sampah plastik masih menjadi permasalahan 
tersendiri bagi para petani KPG. Berdasarkan hasil observasi, hampir semua kebun petani KPG yang dikunjungi memiliki masalah dalam hal sampah plastik yang dibuang secara sembarangan di kebun-kebun mereka. Belum ada petani kopi KPG yang melakukan penanganan secara serius terkait hal ini, padahal mereka menyadari bahwa sampah plastik dapat mengurangi kesuburan tanah di kebun mereka.

Di dalam standar FT mengenai perlindungan lingkungan, para produsen memang dilarang untuk menggunakan bibit atau organisme yang merupakan hasil rekayasa organik. Hal ini dilakukan untuk mengurangi dampak negatif bagi lingkungan yang ditimbulkan dari keberadaan organisme hasil rekayasa genetik. Para petani KPG sendiri dalam hal ini, khusus untuk tanaman kopi melakukan pembibitan sendiri, dibandingkan dengan membeli bibit dari luar yang tidak diketahui asal usulnya. Di bawah pembinaan KPG, para petani KPG mempunyai sentra-sentra pembibitan kopi yang tersebar di beberapa wilayah Kabupaten Bener Meriah dan Aceh Tengah. Selain lebih murah penggunaan dengan menggunakan bibit hasil pembibitan sendiri jauh lebih aman dikarenakan tidak tidak semua bibit dari luar cocok untuk ditanam di wilayah perkebunan mereka.

Langkah lain yang harus dilakukan oleh para produsen di dalam FT untuk perlindungan lingkungan adalah dengan menjaga keanekaragaman hayati. Bentuk-bentuk pelaksanaannya adalah dengan menggunakan sistem agroforestry (adanya tanaman peneduh dan tanaman alternatif), berikut juga dengan menjaga kesuburan tanah. Beberapa hasil penelitian menunjukkan bahwa pada budidaya kopi dengan sistem agroforestry (menggunakan tanaman peneduh, dan penanaman tanaman alternatif lain di perkebunan kopi) berpengaruh pada peningkatan keanekaragaman dan kekayaan jenis mahluk lainnya, seperti burung, semut, termasuk serangga predator alami hama kopi (Onrizal et al., 2011). Namun demikian, pelaksanaan perlindungan oleh petani KPG dalam rangka menjaga keanekaragaman hayati tampaknya masih kurang. Saat ini budidaya kopi yang mulai mengarah kepada pola agroforestry belum sepenuhnya efektif dilakukan oleh para petani. Kebanyakan tanaman yang ditanam adalah tanaman pelindung berupa lamtoro dan jeruk, dengan dominasi lamtoro yang lebih tinggi dibandingkan dengan yang lainnya.

Selain masih minimnya jenis tanaman yang ditanam pada perkebunan petani kopi KPG, kurangnya perlindungan lingkungan oleh petani dalam hal menjaga keanekaragaman hayati dapat dilihat dari semakin berkurangnya tanaman-tanaman seperti alpukat, terong belanda, markisa dan pisang yang dulu cukup banyak di wilayah tersebut. Bahkan beberapa waktu lalu, tanaman pisang di wilayah Bener Meriah mengalami serangan hama penyakit yang hingga kini penyebabnya tidak diketahui. Akibatnya hampir 70\% tanaman pisang di wilayah tersebut mati. Selain itu, tanaman terong belanda dan marikisa yang dulu merupakan produk khas wilayah setempat (selain kopi), sekarang semakin sulit ditemukan. Sekarang kebanyakan terong belanda (C) 2012, Program Studi Ilmu Lingkungan Program Pasca Sarjana UNDIP di Bener Meriah misalnya, didatangkan dari daerah lain, seperti Sumatera Utara.

Masih belum maksimalnya peran petani kopi KPG dalam hal menjaga keanekaragaman hayati dapat dilihat juga dari masih banyaknya serangan hama penggerek buah kopi di perkebunan-perkebunan mereka. Hal ini mengindikasikan bahwa keberadaan predator alami dari hama tersebut masih belum pulih atau masih kurang dibandingkan dengan jumlah hama populasi hama penggerek buah. Keberadaan hama ini akan sangat berpengaruh kepada kualitas biji kopi yang diproduksi. Biji kopi yang telah terkena hama penggerek buah, akan turun grade-nya, dan begitu pula harganya. Untuk itu ke depannya budidaya kopi dengan sistem agroforestry harus dilakukan secara maksimal oleh para petani, agar para petani mendapatkan manfaat jangka panjang seperti yang dikemukakan oleh Sutanto (2002), yaitu menunjang keberadaan musuh alami (bagi hama) dan menurunkan risiko munculnya hama susulan lain.

Poin terakhir, pengurangan emisi GRK juga merupakan bentuk perlindungan lingkungan yang harus dilakukan oleh para produsen di dalam FT. Masih kurangnya penerapan sistem agroforestry dalam perkebunan kopi petani KPG juga memberikan pengaruh kepada tindakan mitigasi dalam hal pengurangan emisi GRK yang juga belum dilaksanakan sepenuhnya oleh para petani KPG. Pertanian rentan terhadap perubahan iklim, namun memiliki potensi untuk mengurangi perubahan iklim melalui pengurangan emisi, peningkatan penyerapan karbon, peningkatan keanekaragaman hayati dan memelihara habitat alami.

Menurut penelitian dari Arief et al. (2011) kemampuan kebun kopi dalam hal menjaga simpanan karbon dapat mencapai 100 ton/ha dan dapat ditingkatkan dengan menanam pohon pelindung yang lebih bervariasi. Sementara hasil penelitian Onrizal et al. (2011) menunjukkan bahwa budidaya kopi dengan sistem agroforestry memiliki simpanan karbon sekitar $150 \%$ lebih besar dibandingkan dengan sistem pelindung monokultur. Dengan demikian, semakin banyak tanaman peneduh dan juga berbagai tanaman alternatif lain yang ditanam di dalam perkebunan kopi petani, semakin tinggi pula laju penyerapan karbon. Dengan peningkatan tanaman pelindung, secara teori akan meningkatkan kestabilan suhu mikro dan berada dalam rentang suhu untuk mendukung produksi optimal, sehingga produksi kopi diharapkan lebih tinggi dari saat ini. Namun demikian, pada petani KPG, tindakan mitigasi ini masih belum maksimal dilakukan. Karena penerapan sistem agroforestry dalam perkebunan kopi mereka masih kurang, maka dampak akan peningkatan produksi kopi mereka juga masih kurang dirasakan.

Selain mitigasi, bentuk adaptasi dalam rangka menghadapi perubahan iklim juga perlu dilakukan oleh petani. Hal ini diperlukan terutama untuk memperkuat keberlanjutan sistem produksi lokal. Salah satu cara yang dapat dilakukan oleh petani adalah dengan menurunkan ketergantungan kepada input eksternal (FLO, 2011). Terkait dengan hal ini, para petani telah 
melakukan adaptasi tersebut dengan cara mengurangi penggunaan herbisida dan bahan-bahan kimia dalam perawatan kopi mereka.

\section{Masalah-Masalah Lingkungan yang Dihadapi oleh Petani Kopi KPG.}

Isu-isu tersebut muncul berdasarkan hasil audit dari FLO, dan juga hasil evaluasi dari KPG sendiri. Menurut penuturan para petani, isu hama penggerek buah adalah yang paling penting untuk ditangani secepatnya. Namun demikian, hingga saat penelitian ini dilakukan penanganan masih terbatas pada teori saja, belum ada prakteknya secara langsung. Para petani sendiri sulit untuk memahami langkah penanganannya jika pelatihan hanya berdasarkan teori saja.

Tabel 1. Isu dalam Perlindungan Lingkungan yang Sulit Ditangani oleh Para Petani KPG

\begin{tabular}{|c|c|c|c|}
\hline No & Isu & Masalah & Penanganan \\
\hline 1. & $\begin{array}{l}\text { Hama \& } \\
\text { Penyakit }\end{array}$ & $\begin{array}{l}\text { Dapat } \\
\text { menurunkan } \\
\text { jumlah } \\
\text { produksi }\end{array}$ & $\begin{array}{l}\text { Melaksanakan } \\
\text { pelatihan } \\
\text { penanggulangan } \\
\text { dan penyediaan } \\
\text { material } \\
\text { penanggulangan }\end{array}$ \\
\hline 2. & $\begin{array}{l}\text { Kesuburan } \\
\text { Tanah }\end{array}$ & $\begin{array}{l}\text { Persepsi } \\
\text { petani } \\
\text { terhadap } \\
\text { pemakaian } \\
\text { bahan kimia } \\
\text { sintetis } \\
\text { mampu } \\
\text { meningkatkan } \\
\text { hasil produksi } \\
\text { dan efesiensi } \\
\text { tenaga kerja }\end{array}$ & $\begin{array}{l}\text { Penyediaan } \\
\text { pupuk organik } \\
\text { dan pelatihan } \\
\text { pembuatan } \\
\text { kompos serta } \\
\text { menyediakan } \\
\text { material } \\
\text { kompos }\end{array}$ \\
\hline 3. & $\begin{array}{l}\text { Limbah } \\
\text { Rumah } \\
\text { Tangga }\end{array}$ & $\begin{array}{l}\text { Tidak } \\
\text { tersedia bak } \\
\text { penampungan } \\
\text { sampah serta } \\
\text { kurangnya } \\
\text { kesadaran }\end{array}$ & $\begin{array}{l}\text { Sosialisasi } \\
\text { dampak sampah } \\
\text { rumah tangga } \\
\text { dan } \\
\text { meminimalisasi } \\
\text { sampah }\end{array}$ \\
\hline
\end{tabular}

Sumber: KPG, 2012

Keberadaan hama penggerek buah di perkebunan kopi di Dataran Tinggi Gayo pada umumnya terdapat pada perkebunan yang ketinggiannya $<1000 \mathrm{~m}$ dpl. Namun untuk beberapa kasus hama penggerek buah ini justru juga menyerang wilayah perkebunan kopi yang ketinggiannya $>1000 \mathrm{~m}$ dpl. Hal ini diakibatkan oleh dua kemungkinan. Pertama, hilangnya musuh alami dari hama penggerek buah tersebut akibat berkurangnya keragaman spesies di wilayah perkebunan tersebut. Keragaman adalah salah satu prinsip dalam lingkungan yang sangat diperlukan dalam kerangka perlindungan tanaman, termasuk dari serangan hama dan penyakit. Semakin rendah tingkat keragaman dalam suatu ekosistem, maka akan semakin rentan pula spesies dalam ekosistem tersebut terserang hama dan penyakit. Kedua, tingginya ketergantungan petani KPG pada herbisida pada masa lalu secara tidak (C) 2012, Program Studi Ilmu Lingkungan Program Pasca Sarjana UNDIP langsung menyebabkan hama penggerek buah tersebut musnah. Namun sekarang, saat mereka tidak lagi menggunakan bahan-bahan kimia tersebut, hama yang dulunya hilang dan musnah kembali menyerang. Sementara, musuh alami dari hama tersebut tidak mampu pulih dan berkembang seperti sebelumnya. Praktek penanganan hama yang didukung oleh penyediaan material penanggulangan memang harus secepatnya dilakukan oleh KPG, mengingat dampaknya yang cukup besar bagi penurunan jumlah produksi.

Isu menurunnya kesuburan tanah terkait penggunaan herbisida ternyata masih menjadi prioritas penanganan oleh KPG sendiri. Masalahnya memang terletak pada diri petani sendiri, yang beranggapan bahwa pemakaian bahan kimia dapat meningkatkan hasil produksi dan lebih efisien dalam penggunannya. Selain itu, harganya yang tidak mahal dan massifnya iklan herbisida di berbagai wilayah di Bener Meriah sendiri juga turut mendukung hal ini. Kadang-kadang papan iklan herbisida dipasang di pohon-pohon pelindung di perkebunan kopi milik para petani KPG, tanpa sepengetahuan mereka sendiri. Hal ini menjadi tugas dan tantangan yang cukup berat bagi KPG, karena untuk merubah persepsi dibutuhkan strategi komunikasi yang tepat.

Tabel 2. Identifikasi Dampak Perlindungan Lingkungan Bagi Petani Kopi KPG

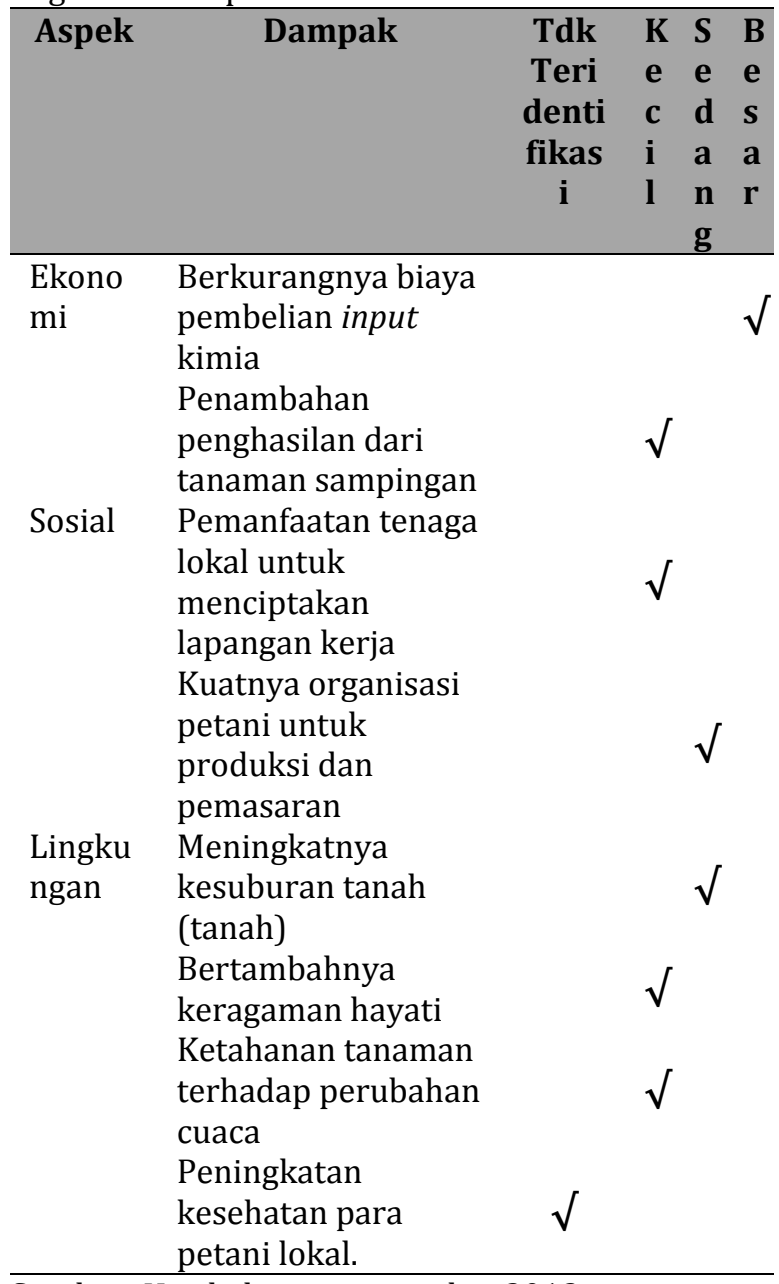

Sumber: Hasil observasi peneliti, 2012 
Isu yang terakhir adalah isu mengenai limbah rumah tangga, berupa sampah non-organik seperti plastik yang terdapat di perkebunan mereka. Ada dua hal yang menyebabkan hal ini terjadi. Pertama, kurangnya kesadaran masyarakat untuk membuang sampah pada tempatnya.. Apalagi bagi mereka yang lokasi kebunnya dekat atau berada di belakang rumahnya langsung, jumlah sampahnya akan lebih banyak lagi. Beberapa petani juga mengeluhkan, bahwa kadang sampah-sampah tersebut bukanlah sampah mereka. Namun tidak memungkinkan bagi mereka untuk terus menerus mengawasi kebun mereka agar terhindar dari sampah.

Kedua, tidak tersedianya tempat penampungan sampah terpadu, di masing-masing desa. Fasilitas penampungan sampah yang telah disediakan oleh pemerintah di beberapa titik tertentu di Bener Meriah sangat kurang dan tidak mudah dijangkau masyarakat. Sehingga sampah-sampah yang ada di desa-desa tidak dapat dijangkau oleh pemda dan masyarakat dengan mudah membuang sampah di mana saja, atau membakarnya. Masalah penanganan sampah nonorganik seringkali juga menjadi perhatian FLO saat melakukan audit atau monitoring.

\section{Identifikasi Dampak Pelaksanaan Perlindungan Lingkungan dalam FT bagi Para Petani Kopi KPG.}

Berdasarkan hasil observasi dan wawancara, maka dampak-dampak dari pelaksanaan perlindungan lingkungan yang dapat diidentifikasi dapat dilihat pada Tabel 2.

\section{A. Dampak Ekonomi}

1. Berkurangnya biaya pembelian input kimia

Dampak dari berkurangnya biaya pembelian input kimia dapat dibilang cukup tinggi. Hal ini dapat dilihat, bahwa sekitar 90\% petani KPG sudah tidak menggunakan herbisida lagi. Masing-masing petani KPG juga sudah mendapatkan bantuan berupa mesin babat (dari alokasi premium fee), untuk menggantikan peran dari herbisida selama ini.

\section{Penambahan penghasilan dari tanaman sampingan}

Keuntungan ini didapatkan melalui penerapan metode agroforestry, dan petani diwajibkan untuk menanam lebih dari satu jenis tanaman di dalam perkebunannya. Selain karena tanaman kopi yang memang memerlukan tanaman peneduh, keanekaragaman spesies dalam sebuah perkebunan diharapkan dapat memberikan penghasilan tambahan di luar penghasilan dari tanaman inti. Ada prinsip keberlanjutan secara ekonomi di sini, yang dapat membantu perekonomian petani saat mereka berada di luar musim panen kopi. Hal ini setidaknya dapat membantu mengurangi ketergantungan petani KPG terhadap tanaman kopi. Petani KPG sendiri belum mendapatkan pembinaan secara intensif dalam pengembangan atau budidaya tanaman sampingan.

Berdasarkan hasil observasi di perkebunan kopi para petani KPG, ada beberapa macam tanaman yang ditanam di sebagian besar kebun petani kopi KPG, (C) 2012, Program Studi Ilmu Lingkungan Program Pasca Sarjana UNDIP diantaranya lamtoro, jeruk, alpukat, cabai, labu air, hingga labu siam maupun labu kuning. Namun hanya jeruk, alpukat dan cabai saja yang dapat memberikan penghasilan tambahan bagi para petani. Penghasilan yang didapat juga masih minim, karena masih minimnya produksi dan juga akses pasar yang tidak dimiliki oleh petani. Untuk itu dampak ini masih cukup rendah dirasakan oleh petani.

\section{B. Dampak Sosial}

\section{Pemanfaatan tenaga lokal}

Pemanfaatan tenaga lokal ini seharusnya dapat terjadi jika petani menerapkan prinsip agroforestry ataupun sistem tumpang sari, yang secara tak langsung menyebabkan beban kerja petani bertambah. Namun sejauh ini pemanfaatan tenaga lokal oleh petani KPG hanya terjadi pada musim panen saja. Rata-rata petani dapat mempekerjakan 2-3 orang pekerja tambahan saat masa panen. Untuk perawatan kebun sehari-hari biasanya para petani dibantu oleh keluarga mereka sendiri, seperti anak atau istri/suami. Adanya dampak berupa pemanfaatan tenaga lokal masih dirasakan kecil, karena sifatnya yang hanya musiman.

2. Kuatnya organisasi petani dalam produksi dan pemasaran

Dengan adanya label organik dan juga FT yang menandakan bahwa para petani telah melakukan perlindungan lingkungan, tentunya akan memberikan nilai tambah dalam hal pemasaran. Apalagi dengan bantuan dari jaringan yang ada di dalam FT sendiri, organisasi produsen seperti KPG tentunya lebih kuat dibandingkan dengan sebelumnya. Para petani sendiri juga merasa lebih baik dan mudah dalam pemasaran, karena ada kepastian harga dan kontrak dibandingkan dulu. Sementara dalam hal produksi kopi, rata-rata per tahun masih $<1000 \mathrm{~kg} / \mathrm{ha}$. Hal ini sekaligus mengindikasikan bahwa perlindungan lingkungan yang mereka lakukan masih belum maksimal. Untuk itu dampak akan kuatnya organisasi petani dalam hal produksi dan pemasaran dirasa sedang/cukup.

\section{Dampak Lingkungan}

\section{Meningkatnya kesuburan tanah}

Dampak dari meningkatnya kesuburan tanah sebenarnya sudah cukup dirasakan oleh petani. Menurut para petani saat ini kebun mereka terlihat lebih hijau, teratur, dan kondisinya jauh lebih baik. Perbedaan ini sangat terasa saat mereka tidak lagi menggunakan herbisida. Walau demikian, dampak dalam hal bertambahnya kesuburan tanah belum dapat dikatakan tinggi karena: 1 . Masih adanya para petani yang menggunakan herbisida; 2. Hampir semua petani masih mengeluhkan adanya sampah-sampah non organik seperti plastik yang terdapat di kebun mereka; 3. Belum adanya alokasi dari premium fee yang berkaitan dengan penanganan masalah sampah non organik ini. 
2. Bertambahnya keanekaragaman hayati

Hal ini dapat dilihat dengan ditanamnya berbagai macam tanaman peneduh, dan tanaman lainnya di perkebunan mereka yang berfungsi menjaga keseimbangan ekosistem. Namun bertambahnya keragaman hayati tersebut kuantitasnya tidak seberapa dibandingkan dengan tanaman kopi yang ada. Masih kurangnya keanekaragaman hayati dapat dilihat dari beberapa hal yaitu: 1 . Semakin berkurangnya tanamantanaman yang dulu juga merupakan produk khas wilayah setempat (seperti terong belanda dan markisa); 2. Masih adanya serangan hama penggerek buah kopi di perkebunan-perkebunan mereka, hal ini mengindikasikan bahwa keberadaan predator alami dari hama tersebut masih belum pulih atau masih kurang dibandingkan dengan jumlah populasi hama penggerek buah.

\section{Ketahanan tanaman terhadap cuaca}

Ketahanan tanaman (kopi) terhadap cuaca masih terbilang rendah. Hal ini dapat dilihat pada menurunnya jumlah produksi para petani KPG pada tahun 2011 yang lalu, dan beberapa diantaranya diakibatkan tanaman tidak tahan terhadap cuaca.

4. Peningkatan kesehatan para petani lokal.

Sejauh ini perbedaan antara sebelum dan sesudah mereka melakukan perlindungan lingkungan memang tidak dapat dilihat secara kasat mata. Walaupun menurut petani mereka merasakan ada perbedaan, tetapi tidak dapat dibuktikan secara medis, karena petani sendiri tidak pernah memeriksakan diri ke dokter saat mereka masih menggunakan herbisida. Menurut petani, dulu saat mereka masih menggunakan herbisida seringkali merasa pusing dan tidak enak badan. Walaupun sekarang mereka merasakan kondisi kesehatan mereka jauh lebih baik, karena tidak adanya bukti secara medis, maka tidak dapat ditarik kesimpulan/tidak teridentifikasi.

\section{Kesimpulan}

Dampak-dampak pelaksanaan perlindungan lingkungan yang dirasakan oleh para petani KPG dalam FT ini lebih didominasi oleh dampak ekonomi. Hal ini mengingat sifatnya yang memang langsung dirasakan oleh para petani secara cepat, berupa berkurangnya biaya input dari pembelian bahan-bahan kimia. Hal tersebut sebenarnya wajar terjadi, mengingat entry point dari gerakan ini yang memang diawali dari aktivitas perdagangan. Membuat para produsen tersebut mandiri secara ekonomi memang sangat penting dilakukan di awal, agar mereka dapat berdaya secara sosial dan tidak terlalu rentan akan dampak dari degradasi lingkungan yang seringkali diterima oleh produsen kecil tersebut.

Tidak dapat dipungkiri, bahwa instrumen ekonomi memang sangat efektif untuk membuat para petani tersebut tergerak untuk melakukan perlindungan lingkungan. Untuk itu pemberian pemahaman kepada para petani akan prinsip keseimbangan dan peran dari (C) 2012, Program Studi Ilmu Lingkungan Program Pasca Sarjana UNDIP aspek ekonomi, sosial dan lingkungan dalam FT ini akan memakan waktu yang cukup lama, jika tidak diiringi dengan penerapan strategi komunikasi yang tepat. Salah satu strategi yang bisa diterapkan dalam hal perlindungan lingkungan adalah pemberian pelatihan berupa teori berikut praktek secara langsung.

\section{Daftar Pustaka}

Anonim. 2003. Memperjuangkan perdagangan yang lebih adil. Salam, 1, 1-5.

Arief, M.C.W., Tarigan, M., Saragih, R., dan Rahmadani, F 2011. Budidaya kopi konservasi: Berbagi pengalaman dari Kabupaten Dairi Sumatera Utara. Conservation International Indonesia. Jakarta.

Bacon, C. 2005. Confronting the Coffee Crisis: Can fair trade, organic, and specialty coffees reduce smallscale farmer vulnerability in Northern Nicaragua? World Development, 33 (3), 497-511.

BPS Kabupaten Bener Meriah. 2011. Bener meriah dalam angka. BPS Kabupaten Bener Meriah. Bener Meriah.

Gendron, C., Bisailon, V., and Rance, A.I.O. 2009. The institutionalization of fair trade: more than just a degraded form of social action. Journal of Business Ethics, 79, 63-79.

Fairtrade Labelling Organizations. 2005. Fair trade standard. http://www.fair trade.net, 11 Oktober 2011, pk. 18.05 WIB.

$$
\text { 2010. Benefit of fairtrade. }
$$
http://www.fairtrade.net/benefits of fairtrade.ht ml, 23 November 2012, pk. 23.22 WIB.

2011. Standar generik fairtrade untuk organisasi produsen kecil. Terj. dari Fairtrade Generic Standard for Small Producer Organizations Fairtrade International. Bonn.

Koperasi Permata Gayo. 2012. Laporan pengurus KPG dalam RAT tahun 2012 (Tahun buku 2011). KPG, Bandar.

Loureiro, M.L., and Lotade, J. 2005. Do fair trade and eco-labels in coffee wake up the consumer conscience? Ecological Economics, 53, 129-138.

Nuraliyah, Z. 2007. Fair trade di Indonesia (sustainability, equality, and humanity in trade): Optimism between powerless? Jurnal Sosial Politika, 14 (2), 177-199.

Onrizal, Bakti, D., dan Hasanuddin. 2011. Pembangunan kerangka prioritas dan kelembagaan mitigasi GRK untuk sektor berbasis lahan di tingkat daerah: Sebuah potret dari Sumatera Utara. Fakultas Pertanian, Universitas Sumatera Utara, Medan.

Ruben, R., and Fort, R. 2011. The impact of fair trade certification for coffee farmers in Peru. World Development, 40 (3), 570-582.

Salim, E. 2010. Paradigma pembangunan berkelanjutan: pembangunan berkelanjutan, peran dan kontribusi Emil Salim. Dalam Iwan J. A. dan Napitupulu. Kepustakaan Gramedia Populer, Jakarta.

Stenzel, P.L. 2012. The pursuit of equilibrium as the eagle meets the condor: Supporting sustainable development through fair trade. American Business Law Journal, 49 (3), 557-642. 
Suhartana, N. 2008. Pertanian organik mengembalikan kedaulatan petani. Buletin Organis, No. 17/ Thn 4.

Suhartana, N., dan Sumino. 2009. Menuju pemasaran kopi spesial: Studi kasus pemasaran di empat sentra produksi kopi. Jakerpo dan Veco Indonesia. Jakarta.

Sutanto, R. 2002. Pertanian organik, menuju pertanian alternatif dan berkelanjutan. Penerbit Kanisius. Yogyakarta.

Transfairusa. 2010. Permata Gayo Co-op, Indonesia. http://transfairusa.org/node/36220,13 Desember 2011, pk. 20.51 WIB.

Valkila, J., and Nygren, A. 2010. Impacts of fair trade certification on coffee farmers, cooperatives, and laborers in Nicaragua. Agric Hum Values, 27, 321333. 